\title{
Morpho-physiological acclimation to canopy coverage of Araucaria angustifolia during the establishment in the Atlantic Forest, Argentina
}

\author{
Aclimatación morfo-fisiológica durante el establecimiento de Araucaria angustifolia \\ bajo cobertura de canopeo en el Bosque Atlántico, Argentina
}

\author{
Flavia Y Olguin ${ }^{\text {a,b }}$, Ana P Moretti ${ }^{\text {a,b }}$, Martín A Pinazo ${ }^{\text {, }}$, Corina Graciano ${ }^{\text {a,b,d* }}$ \\ ${ }^{\text {a }}$ INFIVE (CONICET- Universidad Nacional de La Plata), La Plata, Argentina. \\ ${ }^{\mathrm{b}}$ CCT CONICET La Plata, La Plata, Argentina. \\ ${ }^{\mathrm{c}}$ INTA EEA Montecarlo, Montecarlo, Misiones, Argentina. \\ *Corresponding author: ${ }^{\mathrm{d}}$ Universidad Nacional de La Plata, Facultad de Ciencias Agrarias y Forestales, \\ Calle 60 y 118, CP1900, La Plata, Argentina, tel.: +54 9221 4189402, corinagraciano@agro.unlp.edu.ar
}

\begin{abstract}
SUMMARY
Araucaria angustifolia is an ecologically and commercially important species of the Atlantic Forest. However, its ability to regenerate continuously under the shade of the canopy in the rainforest is uncertain. The aims were: to evaluate the morpho-physiological responses of araucaria to different intensities of canopy coverage to know its shade acclimation capacity; and to evaluate survival and growth under different shade intensities in gaps. First, seedlings were grown in pots at full sun or under canopy shade and morphophysiological traits were measured after 6 and 12 months. Survival was $100 \%$ under full sun and $40 \%$ under shade. One year after planting, the ability to use high-intensity light was similar in plants under both conditions, although shade plants did not grow and showed little capacity to acclimate to shade. Plants under full sun duplicated their size in six months and had higher capacity to deliver water to the leaves. However, shade plants had higher specific hydraulic conductance. After that, in a field experiment, seedlings were planted in six forest-gaps to record survival and growth for 30 months. Survival was high in all positions within the gaps. In the center of the gaps, where incident radiation was higher, growth was higher. We conclude that araucaria has low ability to acclimate to low radiation, nevertheless, it can survive at least 30 months under the canopy. Consequently, araucaria should not be planted below dense canopy shade. The microenvironment in the center of 195-293 $\mathrm{m}^{2}$ gaps is proper for araucaria growth.
\end{abstract}

Key words: abiotic stress, ecophysiology, Paraná pine, rainforest gaps, sun and shade tolerance.

\section{RESUMEN}

Araucaria angustifolia (araucaria) es una especie del Bosque Atlántico de importancia ecológica y comercial, pero su capacidad para regenerar continuamente bajo dosel es incierta. Los objetivos fueron: evaluar la respuesta morfo-fisiológica de araucaria a diferentes intensidades de cobertura de dosel para conocer su capacidad de aclimatación; y evaluar supervivencia y crecimiento bajo diferentes niveles de cobertura durante su establecimiento en claros del Bosque Atlántico. En experimentos en maceta, plantas jóvenes fueron expuestas a sol pleno y bajo sombra del dosel y se hicieron mediciones morfo-fisiológicas seis y 12 meses después de plantadas. La supervivencia fue $100 \%$ a sol pleno y $40 \%$ bajo sombra. Un año luego de plantar, las plantas tuvieron similar capacidad para usar luz de alta intensidad, pero bajo sombra no crecieron y demostraron baja capacidad de aclimatación a la sombra. Las plantas a sol pleno duplicaron su tamaño en seis meses y presentaron mayor capacidad para conducir agua hacia las hojas. Las plantas bajo sombra presentaron mayor conductividad hidráulica específica. En experimento a campo se plantó araucaria en seis claros del bosque y se registró supervivencia y crecimiento durante 30 meses. La supervivencia fue alta y no se asoció a la posición de las plantas dentro del claro. Los mayores crecimientos se registraron en el centro de los claros. Araucaria tuvo poca capacidad para aclimatarse a bajas radiaciones, pero pudo sobrevivir al menos durante 30 meses. Consecuentemente, no se recomienda su plantación bajo dosel denso. El microambiente en el centro de claros de 195 a $293 \mathrm{~m}^{2}$ fue adecuado para el crecimiento de araucaria.

Palabras clave: estrés abiótico, ecofisiología, pino Paraná, claros, tolerancia al sol y a la sombra.

\section{INTRODUCTION}

Tropical and subtropical forests have heterogeneous light environment. The forest canopy decreases the quanti- ty and changes the quality of light that arrives to the understory and severely limits growth and survival of seedlings of shade-intolerant species (Niinemets 2010). The removal of trees of the upper stratum, either by anthropic interven- 
tion or by natural causes, generates openings in the canopy (gaps) that increase the sunlight that arrive to the understory. However, more subtle changes in the magnitude and spatial distribution of light under closed canopies can also influence long-term survival and recruitment of seedlings (Zhang et al. 2012). Plants can adjust genotype expression in response to those changes in light availability, in order to change phenotype to tolerate or optimize light interception and use (Vieira et al. 2015). Thus, the survival and growth of plants in changing environments highly depend on the ability to acclimate to different micro-environmental conditions (Gianoli and Valladares, 2012) to catch the resources that limit growth.

Araucaria angustifolia (Bertol.) Kuntze (araucaria) is a conifer that represents the predominant species of Araucaria Moist Forests in the Atlantic Forest Biome. The Atlantic Forest is a subtropical forest that extends from the Southeast of Brazil to the Northeast of Argentina. Araucaria Forests occupied 177,600 km in Brazil and 2,100 km² in Argentina (Arnoni Costa et al. 2017). However, during the last two centuries, its population has shrunk, due to the extraction driven by the high quality of araucaria wood and expansion of agricultural areas. Despite its ecological and commercial importance, the capacity of araucaria to regenerate and develop continuously in the native forest is uncertain (Longhi et al. 2018). The study of the ecology and management of tropical and subtropical forests is based on the classification of the species according to the response to relevant disturbances and the need of certain levels of water or light (i.e. pioneer, heliophyte, shade tolerant). Araucaria is considered a long-lived pioneer species that depend on large openings of the canopy to have a successful regeneration (Souza et al. 2014, Longhi et al. 2018). This idea is consistent with the success of araucaria plantations in deforested areas. However, mature araucaria forests have distribution of diameter compatible with species that regenerate under the canopy (Paludo et al. 2011). Consistently, it has been reported that the low availability of light does not limit the natural regeneration of araucaria in the forest and that the species can tolerate and maintain different rates of growth under shade (Duarte and Dillenburg 2000, Duarte et al. 2002, Franco and Dillenburg 2007). Those reports indicate that araucaria can regenerate under native forest canopy. However, native araucaria forests have high mortality and low natural regeneration rates in the understory (Beckert et al. 2014). These results show that it is necessary to deepen the research on possible responses to canopy coverage to determine the causes of the low natural regeneration in the rainforest and to identify the best sites for planting araucaria in native forest restoration programs.

The aims are: 1) to evaluate the morpho-physiological responses of araucaria to different intensities of canopy coverage to know its shade acclimation capacity; 2) to evaluate survivor and growth under different shade intensities in gaps.
The hypothesis is that araucaria has low capacity to acclimate to shade under canopy and therefore, its survival and growth will be lower than in open areas. The originality of this work is that the capacity of araucaria to acclimate to shade is described in an integrative way and related to the causes of the death of araucaria regeneration in the rainforest.

\section{METHODS}

Plant material, growth conditions and coverage treatments. A pot experiment and a field experiment were performed in Campo Anexo Manuel Belgrano (CAMB) belonging to EEA INTA Montecarlo, placed in San Antonio, Misiones, Argentina ( $26^{\circ} 02^{\prime} 56.91^{\prime \prime} \mathrm{S} ; 53^{\circ} 46^{\prime} 14.15^{\prime}$ ' W, 552 $\mathrm{m}$ a.s.l.). The mean annual temperature is $21^{\circ} \mathrm{C}$, with a mean monthly amplitude of $10^{\circ} \mathrm{C}$; mean annual rainfall is $2000 \mathrm{~mm}$, distributed evenly throughout the year. Araucaria seeds were collected from the forest and germinated in trays under a semi-covered greenhouse with shade cloths ( $40 \%$ of irradiance reduction) for both experiments. In the pot experiment, 15-month-old plants were transplanted into 7-L pots filled with 1:1 mixture of soil from the forest and pine bark compost. Twenty-five plants were randomly placed under canopy shade in a remnant native forest and fifteen plants were randomly placed under full sun $(\mathrm{n}=$ 40). Photon flux density of photosynthetic active radiation (PAR) and the red/far-red radiation ratio were measured with a Red Tide USB 650 spectroradiometer (Ocean Optics, Dunedin, Florida, USA), at $670 \mathrm{~nm}$ and $730 \mathrm{~nm}$ respectively. PAR was significantly higher under the full sun $\left(\sim 1800 \mu \mathrm{mol}\right.$ photons $\left.\mathrm{m}^{-2} \mathrm{~s}^{-1}\right)$ than under the canopy $(\sim 300$ $\mu$ mol photons $\left.\mathrm{m}^{-2} \mathrm{~s}^{-1}\right)$. Red:far red ratio was near 1 under the full sun and 0.5 under the canopy shade. In addition, air and soil temperatures and relative humidity were measured with thermo-hygrometers (TFA 30.5000.02, Wertheim, Germany), at midday in 15 plants per treatment to describe the environment. Air temperature was similar in both positions (around $28^{\circ} \mathrm{C}$ ), air relative humidity was higher under the canopy ( $39 \pm 1 \%)$ contrasted with full sun $(32 \pm 2 \%)$. The mean \pm standard error of the height and the collar diameter of the plants at the beginning of the experiment were $28 \pm 4 \mathrm{~cm}$ and $5 \pm 1 \mathrm{~mm}$, respectively. Measurements and destructive sampling were performed in five plants per treatment after the summer (six months after planting) and after the winter (12 months after planting). In the field experiment, 4-month-old araucaria plants were planted in six forest gaps as a grid with a distance of $4 \mathrm{~m} \times 4 \mathrm{~m}, 41$ plants per gap $(n=246)$. Extended gap sizes varied between 195 to $293 \mathrm{~m}^{2}$, considered medium gaps in tropical rain forests (Brokaw 1982, De Lima and De Moura 2008). Canopy openness and transmitted light were estimated with hemispherical photographs taken in the center of each gap (table 1). Pictures were taken before sunrise to avoid sunfleck distortions in the images. Photographs were taken with a $180^{\circ}$ fish-eye Nikon FC-E9 lens with a $1 \mathrm{~m}$ height system 
Table 1. Description of the gaps used to plant A. angustifolia in the field experiment.

Descripción de los claros utilizados para plantar araucaria en el experimento a campo.

\begin{tabular}{cccc}
\hline Gap & $\begin{array}{c}\text { Area } \\
\left(\mathrm{m}^{2}\right)\end{array}$ & $\begin{array}{c}\text { Canopy openness } \\
(\%)\end{array}$ & $\begin{array}{c}\text { Transmitted total } \\
\text { light }(\%)\end{array}$ \\
\hline 1 & 293.0 & 20.9 & 24.3 \\
2 & 264.5 & 21.4 & 32.3 \\
3 & 194.7 & 27.9 & 42.1 \\
4 & 222.1 & 38.0 & 50.5 \\
5 & 214.9 & 25.1 & 46.3 \\
6 & 220.3 & 23.2 & 30.5 \\
\hline
\end{tabular}

self-leveling SML-6, Delta T Devices system, adapted to the Nikon Coolpix 8400 digital camera with a Nikon URE16 adaptor and analyzed with GLA (Gap Light Analyzer) software (Frazer et al. 1999). The mean \pm standard error of plant height was $21 \pm 4 \mathrm{~cm}$ at the beginning of the experiment. The different within-gap positions were represented by concentric rings, with ring 1 representing the center of the gap and ring 4 representing the external border of the gap. PAR was measured with a ceptometer (Cavadevices, Buenos Aires, Argentina), at the beginning of the experiment, one measurement above each plant at noon (figure 1). Both experiments were complementary: in the pot experiment, destructive samplings were performed, while the field experiment long-term growth and survival were evaluated, because plant growth was not limited by the pot.

Growth measurements. In both experiments, survival was registered by counting alive plants and height was measured with metal tape every six months. The pot experiment lasted one year, while the field experiment was measured for 30 months. Collar diameter was measured with digital caliper since the beginning in the pot experiment and since the first year after planting in the field experiment. In the pot experiment, the number of whorls with branches and the number of total branches per plant were recorded. Also, the total dry weight for taproots, fine roots, stems and leaves was measured after drying at $65^{\circ} \mathrm{C}$ to constant weight. Root to shoot (stems + leaves) dry weight ratio was calculated.

Leaf traits and hydraulic structure (Pot experiment). Specific leaf area (SLA) was measured on five upper- latest expanded leaves per plant. Leaves were scanned and the area calculated with the software Image Tool v. 1.28 CMEIAS Update. Leaf area of the whole plant (whole-plant LA) was estimated from the multiplication between the SLA and the total dry weight of leaves. Leaf area ratio (LAR) was calculated as leaf area divided by total plant dry weight. Chlo-

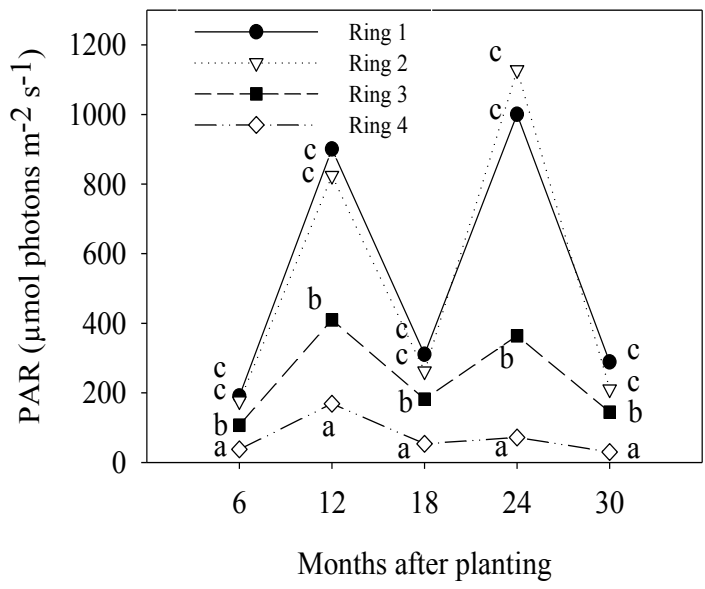

Figure 1. Photon flux density of photosynthetic active radiation (PAR) for each ring at noon along 30 months after planting: 6, 18 and 30 months are in autumn, while 12 and 24 months are in spring. Rings are concentric: ring 1 is the center of the gap, while ring 4 is the outer. Different letters indicate significant differences between means for each date (Kruskal Wallis test, $P<0.05$ ).

Densidad de flujo de fotones de la radiación fotosintéticamente activa (PAR) para cada anillo al mediodía a lo largo de 30 meses después de la plantación: 6,18 y 30 meses son en otoño, mientras 12 y 24 meses son en primavera. Los anillos son concéntricos: anillo 1 es el centro del gap, mientras que el anillo 4 es el borde. Letras diferentes indican diferencias significativas entre medias para cada fecha (Kruskal Wallis, $P<0,05$ ).

rophyll a, chlorophyll $\mathrm{b}$, total chlorophyll and carotenoids were extracted during $48 \mathrm{~h}$ in dark from one intact leaf section of $6.25 \mathrm{~mm}^{2}$ in 1-mL of N, N-dimethylformamide. Absorbance at 664, 647 and $480 \mathrm{~nm}$ wavelength were read with a spectrophotometer (UV-160A, Shimadzu, Kyoto, Japan) (Wellburn, 1994) in one sample per plant. Chlorophyll $\mathrm{a} / \mathrm{b}$ ratio was calculated and interpreted as acclimation changes of the proportion of the antenna complex regarding photosystem reaction centers. Chlorophyll concentration was expressed in leaf area basis $\left(\mu \mathrm{g} \mathrm{cm}^{-2}\right)$ and leaf dry weight basis ( $\left.\mathrm{mg} \mathrm{g}^{-1}\right)$, considering SLA of each plant.

The response of photosynthesis to light was analyzed through the measurement of photosystem II electron transport rate (ETR) at different PAR levels using a chlorophyll fluorometer (FMS2, Hansatech, Norfolk, UK). Measurements were performed on the upper-latest expanded and not shaded leaves, under natural light conditions along the day. Potential functions $\left(E T R=a\right.$ PAR $\left.^{b}\right)$ were selected to adjust data of each treatment and sampling date because that model had lower Bayesian information criterion (BIC) and Akaike Information Criterion (AIC) concerning lineal, polynomial, exponential and logarithmic functions. Maximum quantum yield of photosystem II ( $\mathrm{Fv} / \mathrm{Fm})$ was measured on the same plants with the saturating pulse method (FMS2, Hansatech, Norfolk, UK) after 30 minutes of dark acclimation to ensure the relax of non-photochemical dissipation mechanisms. 
To know the capacity of araucaria seedlings to conduct water to the photosynthetic tissues under different canopy coverage, the hydraulic conductivity of the main stem $\left(\mathrm{kh}_{\text {stem }}\right)$, the hydraulic conductance of the root system $\left(\mathrm{K}_{\text {root }}\right)$ and the shoot (stem + leaves) $\left(\mathrm{K}_{\text {shoot }}\right)$ were measured with the pressure-drop hydraulic flow meter (Melcher et al. 2012). The perfusion was done with de-gassed filtrated distilled water, using $4.5 \mathrm{kPa}$ pressure. The main stem was cut at collar. Afterwards, another cut was performed 1-cm above the collar under water and immediately connected to the measuring system. Hydraulic conductance was measured when the water flow was stable. Subsequently, the portion with leaves and branches were cut and the hydraulic conductivity of the stem basal portion ( $10 \mathrm{~cm}$ long) was measured. To measure the hydraulic conductance of the root, the final part of the main root was cut to perfuse water from the tip-root to the collar of the plant. The root was always kept under water during the measurement. Hydraulic conductance of the whole plant $\left(\mathrm{K}_{\text {plant }}\right)$ was calculated as equation 1 .

$$
\mathrm{K}_{\text {plant }}=1 /\left(1 / \mathrm{K}_{\text {root }}+1 / \mathrm{K}_{\text {shoot }}\right)
$$

The standardized conductance of the whole plant was obtained as $\mathrm{K}_{\text {plant }}$ divided by dry weight of the whole plant $\left(\mathrm{K}_{\text {plant }}\right.$ : total DW). Shoot conductance was expressed both divided by its dry weight $\left(\mathrm{K}_{\text {shoot }}\right.$ : shoot $\left.\mathrm{DW}\right)$ and on leaf area basis $\left(\mathrm{K}_{\text {shoot }}: \mathrm{LA}\right)$. The conductivity of the root was divided by its dry weight $\left(\mathrm{K}_{\text {root }}:\right.$ root $\left.\mathrm{DW}\right)$. The specific hydraulic conductivity of the stem $\left(\mathrm{ks}_{\text {stem }}\right)$ and the leaf specific hydraulic conductivity of the stem $\left(\mathrm{kl}_{\text {stem }}\right)$ were calculated as the ratio between $\mathrm{kh}_{\text {stem }}$ and the cross-section of the sapwood and leaf area, respectively.

Statistical analyses. PAR in the field experiment had no normal distribution; therefore, non-parametric analysis with Kruskal Wallis test, $P<0.05$ was done, to compare means in each date.

Morphological and physiological modifications analyzed here will be interpreted as responses to changes in all the environmental variables that are modified when plants acclimate to full sun compared to plants acclimated to canopy shade. In the pot experiment, ANOVA $(P<0.05)$ was performed with coverage (full sun and canopy shade) and growth time (6 and 12 months) as factors; the interaction between factors was analyzed. As interactions were significant, means were compared with the post hoc analyses DGC test $(P<0.05)$ (Di Rienzo et al. 2002). In the field experiment, height and collar diameter were analyzed with General Mixed Linear Models $(P<0.05)$, with withingap position (rings) and date as fixed factors and gap as random factor. Interaction was analyzed. As interactions were significant, means were compared with DGC test $(P$ $<0.05$ ). Survival at 30 months after planting was analyzed by nonparametric ANOVA, with the Kruskal Wallis test, $P$ $<0.05$. All analyses were done with software Infostat ( $\mathrm{Di}$ Rienzo et al. 2017).

\section{RESULTS}

Pot experiment. Survival was $100 \%$ under full sun and $40 \%$ under canopy shade, six and 12-months after planting. At the end of the pot experiment, height, collar diameter, number of branches and number of whorls with branches were higher in plants growing under full sun than in those growing under the canopy shade (figure 2). Collar diameter, number of branches and number of whorls increased along time in plants under full sun while these traits did not increase in plants under canopy shade (figure 2). Total and stem dry weight increased over time only in plants under full sun (table 2). Shoot to root ratio was similar in plants under full sun and under canopy shade and steady over time (table 2). Root dry weight was similar in plants under full sun and under canopy shade six months after planting. However, plants under full sun invested more dry weight in fine roots contrasted with plants under canopy shade (table 2). Leaf dry weight was higher in plants under full sun than in plants under canopy shade, six and 12 months after planting. The shoot dry weight (stems + leaves) doubled in 6 months in plants under full sun while it did not increase in plants under canopy shade (table 2).

Whole-plant leaf area (LA) was higher in plants under full sun than in plants under canopy shade in both sampling dates (table 2). The leaf area ratio (LAR) was higher in plants under canopy shade than in plants under full sun and it decreased in both treatments between six and 12 months after planting (table 2). The specific leaf area (SLA) was always higher in plants under canopy shade than in plants under full sun and SLA decreased over time in both treatments (table 2). Chlorophyll concentration per leaf area was higher in plants under full sun than in plants under canopy shade and it was similar over the time in both conditions (table 2). The chlorophyll concentration per leaf weight and chlorophyll $\mathrm{a} / \mathrm{b}$ ratio were similar in both treatments and sampling dates (table 2). Carotenoid concentration in leaf area basis was higher in plants under full sun, while carotenoid concentration in leaf dry weight basis decreased in both treatments, 12 months and six months after planting.

The capacity to conduct water of whole plants $\left(\mathrm{K}_{\text {plant }}\right)$ as well as of organs ( $\left.\mathrm{K}_{\text {shoot }}, \mathrm{K}_{\text {root }}, \mathrm{kh}_{\text {stem }}\right)$ was similar in plants under full sun and under canopy shade 6 months after planting (table 3). $\mathrm{K}_{\text {shoot }}$ and $\mathrm{K}_{\text {plant }}$ increased a year after planting in plants under full sun, but not in plants under canopy shade. Conversely, $\mathrm{K}_{\text {root }}$ and $\mathrm{K}_{\text {root }}$ : root DW increased one year after planting in plants under canopy shade, but not in plants under full sun (table 3 ). The conductance of the whole-plant standardized by total dry weight $\left(\mathrm{K}_{\text {plant }}\right.$ : total $\left.\mathrm{DW}\right)$ and the conductance of the shoot standardized by shoot dry weight $\left(\mathrm{K}_{\text {shoot }}\right.$ : shoot $\left.\mathrm{DW}\right)$ and by leaf area $\left(\mathrm{K}_{\text {shoot }}: \mathrm{LA}\right)$ were higher in plants under canopy shade than in plants under full sun (table 3). Therefore, plants under full sun had higher conductance because they were bigger than plants under canopy shade. The capacity to driving water of the 


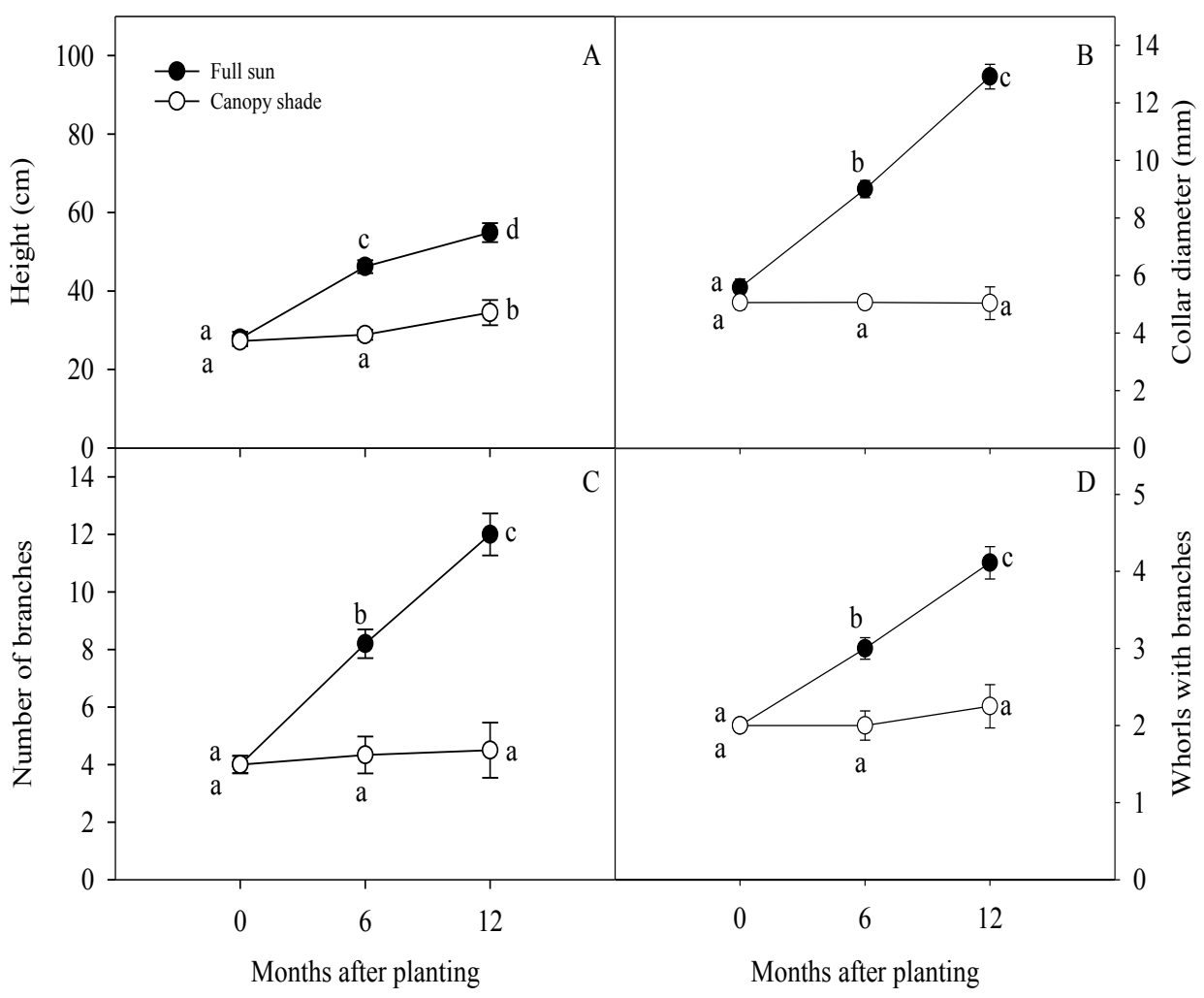

Figure 2. Height (A), collar diameter (B), number of the total branches (C) and number of whorls with branches (D) during the first year in the pot experiment. As interaction between treatment $\mathrm{x}$ date was significant for all the variables, different letters show significant differences between means (DGC, $P<0.05$ ).

Altura (A), diámetro basal (B), número de ramas total (C) y número de nudos con ramas (D) durante el primer año en el experimento en macetas. Como la interacción entre factores fue significativa, letras diferentes indican diferencias significativas entre medias $(\mathrm{DGC}, P<0,05)$.

stem $\left(\mathrm{kh}_{\text {stem }}\right)$ was similar between coverage in both sampling dates, i.e. a segment of stem had the same capacity to conduct water, and increased with time. The capacity to conduct water to hydrate leaves $\left(\mathrm{kl}_{\text {stem }}\right)$ was higher in plants under canopy shade because although $\mathrm{kh}_{\mathrm{stem}}$ was similar, the leaf area to supply was lower in plants under canopy shade. The hydraulic conductivity of the stem standardized by the xylem active area $\left(\mathrm{ks}_{\text {stem }}\right)$ was similar in plants under full sun than in plants under canopy shade (table 3 ).

Field experiment. Survival in each gap 30 months after planting was between 73 and $95 \%$ and mortality was evenly distributed within the gap rings (Kruskal Wallis test; $\mathrm{H}=2.45 ; P=0.46$ ) with a mean survival near $90 \%$ in rings 1,2 and 3 and $81 \%$ in ring 4 . Plants in ring 4 , the ring with denser canopy coverage (figure 1), were shorter and with smaller collar diameter from the first measurement. Differences between rings increased with time. At the end of the experiment, height and collar diameter were higher in the center (ring 1), intermediate in middle rings and lower in the external border of the gaps (ring 4) (figure 4). Therefore, position in the gap did not influence survival, nevertheless it conditioned growth, perhaps gaps were medium size.

\section{DISCUSSION}

Survival and growth. In the pot experiment, survival was low below the canopy shade while in the field experiment survival was high in all the rings and mortality was no associated with within-gap position. Therefore, in the pots, plants could not sustain the cost of acclimation and some plants died, as radiation was very low to have positive carbon gain. This was evident because the survivors under the canopy shade made many morphological and physiological changes to acclimate to low radiation, in spite of their lower growth regarding plants under full sun. Lower growth was reflected in lower height, collar diameter and number of branches 30 months after planting, as both treatments started with the same plant size. Growth graphically can be seen as the slope of each variable along time: lower slope, lower growing rate and vice versa (figure 2). The results obtained in the pot experiment are related to the results in the field experiment, where the highest growth in height and collar diameter was recorded in plants in the positions of gaps with higher radiation (figures 1 and 4), which is straightforward related to coverage. Results suggest that the growth of araucaria under canopy shade during the first 
years is lower than in micro environments with higher level of radiation. Plants acclimated to low irradiances may have higher activity in the apical meristem, leading to reduced branches resulting in taller plants with thinner stems (Valladares and Niinemets 2008). Similar average heights, around $23 \mathrm{~cm}$, were reported in young plants of the same species under controlled conditions with low radiation (200 $\mu$ moles $\mathrm{m}^{-2} \mathrm{~s}^{-1}$ ) (Einig et al. 1999). Contrary to our results, Duarte and Dillenburg (2000) reported higher araucaria height three months after planting at higher irradiances, however after that date, no differences between light conditions were observed. The contradiction may be due to the use of an artificial shade, whereas we used a native forest canopy shade. The proportion of red light (i.e. red: far-red ratio) or the intensity of blue light are essential in the morphogenetic response of plants to the environment and an ar- tificial shade may not produce the same effect than a natural canopy. On the other hand, Franco and Dillenburg (2007) reported higher araucaria heights 3 months after planting at lower irradiance, where the growth in light-limiting conditions could have been favored by the mobilization of the storage compounds of the seeds (Einig et al. 1999). However, no increase in height was recorded after that period in shade plants, whereas plants at full sun increased in height and increased investment in branching. This last response coincides with the growing response described in our pot experiment (figure 2), possibly because the measurements were done six months after setting the coverage conditions. Although increase in height can be a helpful response to a short duration shade, conserving photoassimilates to sustain respiration may be more advantageous under continuous shading (Franco and Dillenburg, 2007).

Table 2. Dry weight partition and pigment concentration in the pot experiments in full sun and canopy shade treatments at six and 12 months; Shoot/Root: relationship between shoot dry weight and root dry weight; SLA: specific leaf area of plant; LA: leaf area of plant; LAR: leaf area ratio (LA/total dry weight); Chlorophyll a/b: relationship between chlorophyll a and chlorophyll b. Significant interaction or significant factors are indicate as: $*=P<0.05 ; * *=P<0.01 ; * * *=P<0.001$ and ns $=$ no significant. If the interaction CxT is significant, different letters show significant differences between means $(P<0.05)$.

Partición en peso seco y concentración de pigmentos en el experimento en macetas en los tratamientos sol pleno y sombra de canopeo a seis y 12 meses; Shoot/Root: relación entre el peso seco del vástago y el peso seco de la raíz; SLA: área foliar específica; LA: área foliar de la planta; LAR: relación de área foliar (LA/peso seco total); Chlorophyll a/b: relación entre clorofila a y clorofila b. La interacción o los factores significativos están en negrita. Si la interacción es significativa, letras diferentes indican diferencias significativas entre las medias $(P<0,05)$.

\begin{tabular}{|c|c|c|c|c|c|c|c|}
\hline \multirow[b]{2}{*}{ Variable } & \multicolumn{2}{|c|}{6 months } & \multicolumn{2}{|c|}{12 months } & \multicolumn{3}{|c|}{$P$-value } \\
\hline & $\begin{array}{l}\text { Full } \\
\text { sun }\end{array}$ & $\begin{array}{c}\text { Canopy } \\
\text { shade }\end{array}$ & $\begin{array}{l}\text { Full } \\
\text { sun }\end{array}$ & $\begin{array}{c}\text { Canopy } \\
\text { shade }\end{array}$ & Coverage & Time & CxT \\
\hline Total dry weight (g) & $30^{(\mathrm{b})}$ & $4^{(\mathrm{c})}$ & $80^{\text {(a) }}$ & $7^{\text {(c) }}$ & $* * *$ & $* * *$ & $* *$ \\
\hline Taproot dry weight (g) & $4^{\text {(b) }}$ & $1^{\text {(b) }}$ & $15^{\text {(a) }}$ & $2^{\text {(b) }}$ & $* * *$ & $* *$ & $*$ \\
\hline Fine root dry weight $(\mathrm{g})$ & $4^{\text {(b) }}$ & $1^{(\mathrm{c})}$ & $10^{\text {(a) }}$ & $1^{\text {(c) }}$ & $* * *$ & $* *$ & $* *$ \\
\hline Root dry weight (g) & $8^{\text {(b) }}$ & $1^{\text {(b) }}$ & $25^{\text {(a) }}$ & $2^{(\mathrm{b})}$ & $* * *$ & $* *$ & $* *$ \\
\hline Leaf dry weight (g) & $15^{\text {(b) }}$ & $2^{\text {(c) }}$ & $28^{\text {(a) }}$ & $2^{(\mathrm{c})}$ & $* * *$ & $*$ & $*$ \\
\hline Stem dry weight (g) & $8^{\text {(b) }}$ & $1^{\text {(b) }}$ & $27^{\text {(a) }}$ & $2^{(\mathrm{b})}$ & $* * *$ & $* * *$ & $* *$ \\
\hline Shoot dry weight (g) & $23^{(\mathrm{b})}$ & $3^{\text {(c) }}$ & $55^{\text {(a) }}$ & $4^{\text {(c) }}$ & $* * *$ & $* *$ & $* *$ \\
\hline Shoot to Root ratio & 2.98 & 2.67 & 2.30 & 2.35 & ns & ns & ns \\
\hline $\operatorname{SLA}\left(\mathrm{cm}^{2} \mathrm{~g}^{-1}\right)$ & 67 & 86 & 37 & 69 & $* *$ & $* *$ & ns \\
\hline Whole-plant LA $\left(\mathrm{cm}^{2}\right)$ & 989 & 187 & 1054 & 153 & $* * *$ & ns & ns \\
\hline $\operatorname{LAR}\left(\mathrm{cm}^{2} \mathrm{~g}^{-1}\right)$ & 33 & 43 & 13 & 24 & $* *$ & $* * *$ & ns \\
\hline Chlorophyll a/b & 2.06 & 2.31 & 2.01 & 2.17 & ns & ns & ns \\
\hline Total chlorophyll $\left(\mu \mathrm{g} \mathrm{cm}^{-2}\right)$ & 105 & 60 & 115 & 70 & $* *$ & ns & ns \\
\hline Total chlorophyll (mg g-1) & 7 & 5 & 4 & 5 & ns & ns & ns \\
\hline Carotenoids $\left(\mu \mathrm{g} \mathrm{cm}^{-2}\right)$ & 14 & 8 & 14 & 9 & $* *$ & ns & ns \\
\hline Carotenoids (mg g $\left.{ }^{-1}\right)$ & 0.90 & 0.65 & 0.51 & 0.61 & ns & $*$ & $\mathrm{~ns}$ \\
\hline
\end{tabular}

The maximum yield of photosystem $2(\mathrm{Fv} / \mathrm{Fm}$ at dark) remained over 0.80 in both treatments and sampling dates $(\mathrm{F}=1.68 ; P=0.23)$, therefore no damage to the photosynthetic apparatus was registered. Electron transport rate (ETR) at high PAR was higher in plants under full sun than in plants under canopy shade six months after planting (figure 3), whereas the relationship between ETR and PAR was similar in both treatments 12 months after planting (figure 3). 
Morphological acclimation to shade. One of the main mechanism to adjust plant morphology to resource imbalances is assigning biomass to the organs that acquire the strongest limiting resource (Duarte and Dillenburg 2000). The accumulation of total dry weight was significantly lower in plants under canopy shade and there was no carbon gain between measurements (table 2). Shoot, leaf and fine roots dry weights were lower in plants under canopy shade than in plants under full sun (table 2). This response coincides with reports for the same species, with a shade that implied $90 \%$ reduction in sunlight (Duarte and Dillenburg 2000, Franco and Dillenburg 2007) and under full darkness (Dillenburg et al. 2010). A reduction of carbon allocation to the root system may be considered a strategy of shade-tolerant plants to prolong their survival (Valladares and Niinemets 2008), nonetheless in araucaria, under the shade, neither root nor shoot increased in six months. Therefore, there was no growth rather than acclimation. In another point of view, higher investment in roots in plants under high irradiances may be considered a functional response to higher evapotranspiratory demand, that may be related to higher soil temperature and lower relative humidity at full sun compared with the environment under canopy cover. However, in our experiment, shoot to root ratio was similar in plants under full sun and under canopy shade (table 2). Despite, in most of the species studied, an increase in the shoot to root ratio has been evident in response to low irradiances, even for araucaria (Duarte and Dillenburg 2000, Franco and Dillenburg 2007). Therefore, in our experiment, plants under full sun grew markedly and they did not change shoot to root ratio that seems optimal to tolerate full sun conditions; plants under the canopy shade did not grow, hence they could not adjust dry weight partitioning to better tolerate low radiation.

Although there were no changes along the first year after planting in dry weight in plants under canopy shade, there were adjustments of SLA, which was higher in plants under canopy shade in both dates (table 2) as was reported for araucaria (Duarte and Dillenburg 2000, Franco and Dillenburg 2007). It is expected that leaves developed in environments with higher radiation have additional layers of mesophyll, increasing the thickness of the leaf and decreasing its SLA. In contrast, plants developed in environments with lower radiation tend to make morphological modifications to maximize the interception of light with a low carbon investment (Niinemets 2010). Shade plants and shade-tolerant plants allocate more resources to the production of leaves, resulting in higher proportion of leaf area to total dry weight (LAR). For example, in six species

Table 3. Conductance (K) and hydraulic conductivity (k) 6 and 12 months after planting, for full sun and canopy shade treatments in the pot experiment. $\mathrm{K}_{\text {plant }}$ : conductance of whole plant; $\mathrm{K}_{\text {root }}$ : conductance of root; $\mathrm{K}_{\text {shoot }}$ : conductance of shoot (leaves + stem); kh stem: hydraulic conductivity of stem; $\mathrm{ks}_{\text {stem }}$ : specific hydraulic conductivity of stem $\left(\mathrm{kh}_{\text {stem }}\right.$ :xylem area); $\mathrm{kl}_{\text {stem }}$ : specific leaf conductivity of stem ( $\mathrm{kh}_{\text {stem }}$ :leaf area); $\mathrm{K}_{\text {shoot }}: \mathrm{LA}$ : stem conductance standardized by the leaf area of the plant. LA means leaf area, DW means dry weight. Significant interaction or significant factors are indicated as: $*=P<0.05 ; * *=P<0.01 ; * * * P<0.001$ and ns $=$ no significant. If the interaction CxT is significant, different letters show significant differences between means $(P<0.05)$.

Conductancia $(\mathrm{K})$ y conductividad hidráulica $(\mathrm{k})$ seis y 12 meses después de plantadas, para los tratamientos sol pleno y sombra de canopeo en el experimento en macetas. $\mathrm{K}_{\text {plant }}:$ conductancia de la planta; $\mathrm{K}_{\text {root }}:$ conductancia de la raíz; $\mathrm{K}_{\text {shoot }}:$ conductancia del vástago (hojas + tallo); $\mathrm{kh}_{\text {stem }}$ : conductividad hidráulica del tallo; $\mathrm{ks}_{\text {stem }}$ : conductividad hidráulica específica del tallo $\left(\mathrm{kh}_{\text {stem }}\right.$ :area del xilema); $\mathrm{kl}_{\text {stem }}$ : conductividad foliar específica del tallo $\left(\mathrm{kh}_{\text {stem: }}\right.$ : area foliar); $\mathrm{K}_{\text {shoot }}: \mathrm{LA}$ : conductancia del tallo estandarizada por el área foliar de la planta. LA: área foliar media, DW: peso seco medio. La interacción o los factores significativos están en negrita. Si la interacción es significativa, letras diferentes indican diferencias significativas entre las medias $(P<0,05)$.

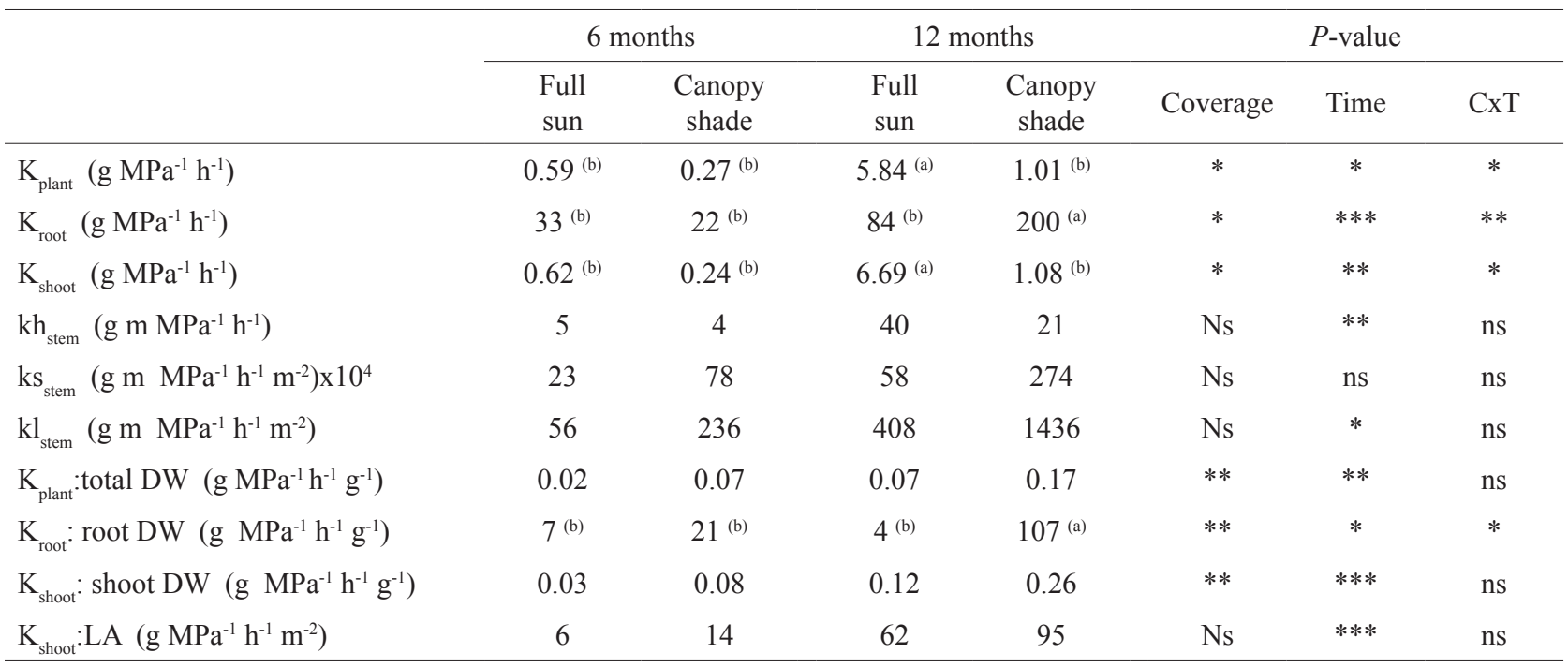




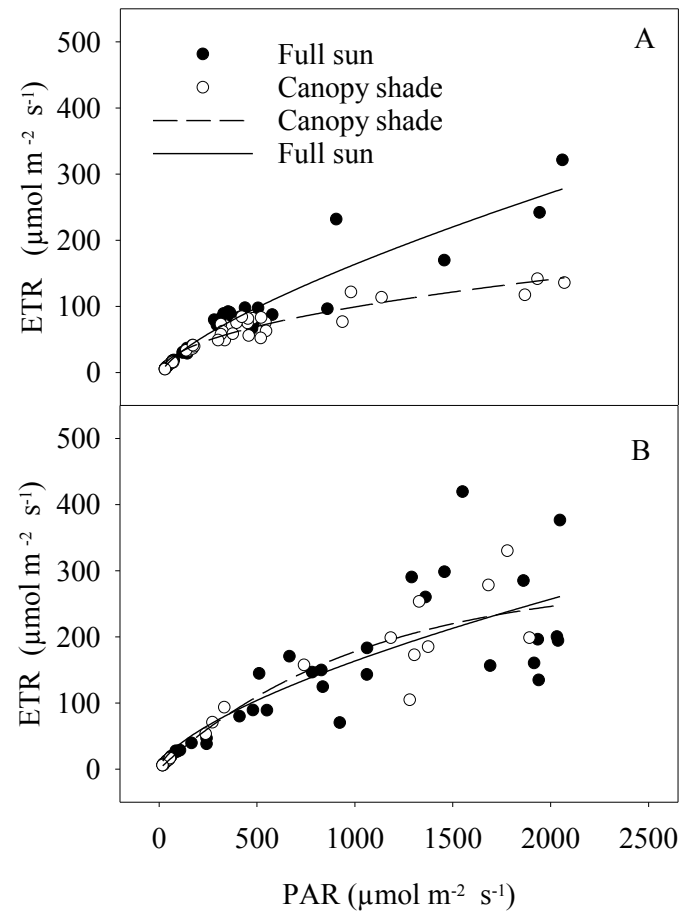

Figure 3. Electron transport rate (ETR, $\mu$ moles $\mathrm{e}^{-} \mathrm{m}^{-2} \mathrm{~s}^{-1}$ ) at

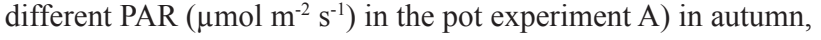
six months after planting, fitted a potential curve with ETR = $1.15 \mathrm{PAR}^{0.72} ; \mathrm{R}^{2}=0.92$ for full sun treatments and $\mathrm{ETR}=3.22$ PAR ${ }^{0.50} ; \mathrm{R}^{2}=0.89$ for canopy shade treatments, $P<0.01$ in both treatments, and B) in spring, 12 months after planting, fitted a potential curve with $\mathrm{ETR}=1.79$ PAR ${ }^{0.65}, \mathrm{R}^{2}=0.76$ for full sun treatment and $\mathrm{ETR}=1.12 \mathrm{PAR}^{0.72} ; \mathrm{R}^{2}=0.89$ for canopy shade treatment, $P<0.01$ in both treatments.

ETR (tasa de transporte de electrones, $\mu$ moles $\mathrm{e}^{-} \mathrm{m}^{-2} \mathrm{~s}^{-1}$ ) a diferentes intensidades de PAR $\left(\mu \mathrm{mol} \mathrm{m} \mathrm{m}^{-2} \mathrm{~s}^{-1}\right)$ en el experimento en macetas A) en otoño, seis meses después de plantadas, ajustada a una curva potencial con $\mathrm{ETR}=1,15 \mathrm{PAR}^{0,72}, \mathrm{R}^{2}=0,92$ para el tratamiento sol pleno y ETR $=3,22 \mathrm{PAR}^{0,50} ; \mathrm{R}^{2}=0,89$ para el tratamiento sombra de canopeo $P<0,1$ en ambos casos, y B) en primavera, 12 meses después de plantadas, ajustada a una curva potencial con $\mathrm{ETR}=1,79 \mathrm{PAR}^{0,65}, \mathrm{R}^{2}=$ 0,76 para el tratamiento sol pleno y ETR $=1,12 \mathrm{PAR}^{0,72} ; \mathrm{R}^{2}=0,89$ para el tratamiento sombra de canopeo, $P<0,01$ en ambos tratamientos.

LAR increased as light intensity decreased (Moraes Neto et al. 2000). Likewise, shade-tolerant temperate gymnosperms had higher LAR than intolerant gymnosperms (Valladares and Niinemets 2008). Consistently LAR was higher in araucaria plants under canopy shade than in plants under full sun; nevertheless, it is important to highlight that there was no increment in leaf area neither in shade plants nor in sun plants. However, unlike shade plants, sun plants increased total dry weight. That means that the higher LAR in araucaria under the canopy shade, contrasted with sun plants, is expressing that dry weight is more reduced than leaf area: i.e. araucaria under the canopy cannot fix carbon, although leaf area persists for six months. After that, LAR decreased over time (table 2). In the case of sun plants this change can be related to a phenological stage because bigger trees have less proportion of leaves compared with stems and roots. In the case of shade pants, this happened because leaf area started to reduce. Therefore, araucaria under canopy shade can increase SLA, although it cannot actively change LAR or shoot to root ratio, because no growth occurs.

Physiological acclimation to canopy shade. Concentration of chlorophyll per gram of leaves was higher in araucaria plants growing under the shade for two months, while chlorophyll $\mathrm{a} / \mathrm{b}$ ratio was similar in plants under shade and full sun (Franco and Dillenburg 2007), as observed in many species. Contrary to expectations, the concentration of chlorophyll per unit area was lower in plants under canopy shade than in plants under full sun, while chlorophyll concentration in dry weight basis and chlorophyll a to $b$ ratio were similar between treatments (table 2). The low concentration of chlorophyll we observed is possibly indicating that araucaria did not achieve a positive carbon balance under high coverage, as reflected in the null growth (figure 2). Similarly, in another study, there were no differences in chlorophyll concentration per leaf area or dry weight, or in chlorophyll $\mathrm{a} / \mathrm{b}$ ratio in araucaria plants growing under different levels of irradiance during 3-months (Duarte et al. 2002). The difference in chlorophyll concentration may be given by the differences in the type of shade of each experiment since in our experiment the reduction of PAR was given by the canopy shade and in other experiments by polyethylene shade cloths. The concentration of photosynthetic pigments may vary in response to light levels and quality. Generally, the leaves acclimated to low irradiances have higher concentration of chlorophyll per unit area and leaf weight, in relation to leaves acclimated to high irradiances to optimize photophosphorylation and, consequently, energy production (Valladares and Niinemets, 2008). In most plants, the proportion of chlorophyll a to $\mathrm{b}$ tends to decrease as shade increases, because chlorophyll $b$ is mainly present in the photosystem 2 antennae that increase their proportion under low irradiances. In light-demanding species, the concentration of chlorophyll increases only in response to a moderate shade (36\% incident light) while under denser shade (8\% incident light) the concentration does not change or even decreases, as in our experiment. However, in shade semitolerant species both moderate and severe shading lead to an increase in chlorophyll concentration (Strauss-Debenedetti and Bazzaz 1991). Therefore, chlorophyll concentration is another physiological trait that shows that araucaria cannot acclimate to the shade.

After six months of acclimation, sun plants were able to fix more carbon at high irradiances than did canopy plants (figure 3). This is consistent with the higher chlorophyll concentration and lower SLA, i.e. thicker leaves of sun plants compared with shade plants. However, after one year, plants acclimated to shade had the same response of 


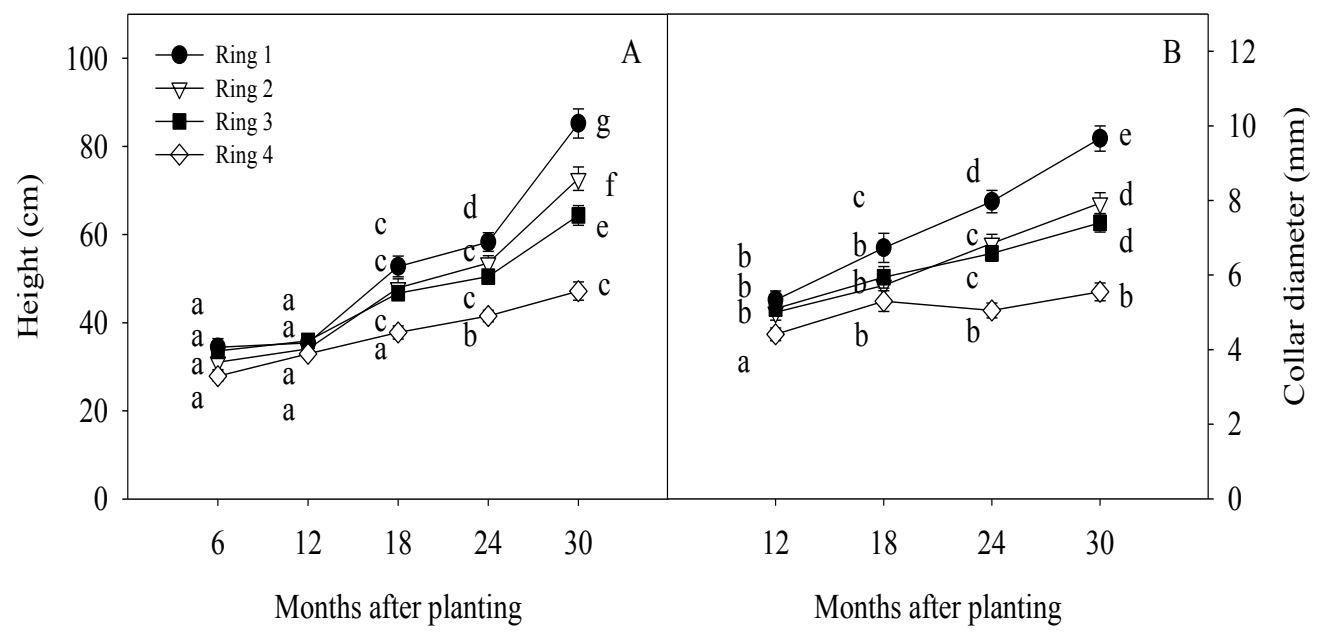

Figure 4. Height and collar diameter in each ring into the gaps along the first 30 months after planting in the field experiment. Rings are concentric: ring 1 is in the center of the gap, with higher incident light and ring 4 is the outer, with lower incident light. As ring $\mathrm{x}$ date interaction is significant in both variables, different letters show significant differences between means $(\mathrm{DGC}, P<0.05)$.

Altura y diámetro basal medio en cada anillo dentro de los claros a lo largo de los primeros 30 meses de plantadas en plantas del experimento a campo. Los anillos son concéntricos: el anillo 1 es el centro del claro, con mayor incidencia de luz, y el anillo 4 es el borde, con menor incidencia de luz. Como la interacción anillo x fecha fue significativo en las dos variables, diferentes letras indican diferencias significativas entre las medias de los anillos (DGC $P<0,05)$.

photosynthesis to irradiation as plants acclimated to full sun (figure 3). A possible explanation is that sun and shade plants decreased SLA between six and 12 months after planting, although any treatment increased chlorophyll concentration in leaf area basis. Therefore, each unit leaf area had the same concentration of chlorophyll, though in a thicker leaf. This possibly reduced ETR to similar values in both treatments. Similar results were reported in coniferous seedlings in understory and in open areas that had a photosynthetic apparatus strongly adapted to high irradiance and did not reduce the light saturation point like a typical adjustment to understory conditions (Landhäusser and Lieffers 2001). Thus, the low growth in canopy shade plants was due to the low incident radiation and the reduced leaf area available for the interception of light (table 2) and not to a noticeable reduction in photosynthetic rate (figure 3 ). This response possibly reflects that the architecture of the plant with imbricates and triangular needles does not allow a considerable increase of leaf area to enhance interception of light.

Physiological acclimation to open areas. A physiological trait that can test if plants under full sun are suffering stress by excess of light is $\mathrm{Fv} / \mathrm{Fm}$. This ratio can take values between 0 and 0.85 and connotes a direct relationship with the percentage of functional centers of photosystem 2 (PSII). In general, a decrease from 0.85 indicates damage and loss of function at photosynthetic apparatus level because the PSII is very susceptible to excess of light, thus the rate of damage is linearly dependent on the photon fluence rate. If plants are suffering by excess of light, $\mathrm{Fv} / \mathrm{Fm}$ should decrease as well as the concentration of chlorophyll. None of these changes occurred in the plants exposed to full sun. The only protection to excess of light was an increment in carotenoids concentration in sun respect to shade plants (table 2). Therefore, according to our results, araucaria could be classified as a lightdemanding species since the concentration of chlorophyll decreased under dense shade (12\% incident light) and there are no signals of stress by excess of light.

On the other hand, in open areas, the evaporative demand is higher than under the canopy due to the higher temperature and air movement. Consequently, the ability of the whole plant and different organs to carry water was higher in plants under full sun than in plants under the canopy shade. However, the capacity standardized by the size was higher in canopy shade plants (table 3). This indicates that plants under canopy shade can drive more water with less investment of dry weight. Possibly the highest specific conductance could be achieved with larger vessels and/or thinner walls (Hacke et al. 2017). Therefore, this higher efficiency of driving water can increase risk of hydraulic failure if the availability of water in the soil decreases or the saturation deficit of the atmosphere increases. Higher vulnerability to cavitation was reported for four conifers, with different shade tolerance, cultivated under canopy of deciduous forest compared with plants growing under full sun (Schoonmaker et al. 2010). Evapotranspiration and temperature are lower under the canopy than under full sun. However, a rapid change in environmental conditions or the occurrence of days with extreme heat and drought can expose plants to situations of high water deficit and produce generalized embolisms. In this situation, the death 
of the plants can occur, as observed in shade plants in our pot experiment six months after planting. Although, a recent study has demonstrated that leaves of araucaria are capable of absorbing water from the atmosphere and that this water can be transported through the xylem to the soil close to the root, to improve plant water status (Cassana et al. 2016). This type of response demonstrates that the species has the ability to adjust its hydraulic architecture one year after planting, to ensure the adequate delivery of water to the leaves under high radiation and evaporative demands, without meaningful water stress.

Finally, we found no evidence that araucaria under full sun or in the open areas in the gaps suffer stress; nevertheless, we found that shade severely limits growth (table 2 and figure 4). Araucaria has nearly no capacity to acclimate to shade, as no active change in morphology or physiology was observed. However, it is very important to highlight that araucaria plants under the shade can survive at least for 30 months in medium gaps (figure 4).

\section{CONCLUSIONS}

Araucaria has low survival under very dense canopies with no dry mass gain. In forest medium gaps, with intermediate shade, the survival is higher than under the dense canopy and mortality is no related with the position of the plant in the gaps. However, growth rate is higher in positions with higher radiation. Consistently, araucaria acclimates properly to full sun and no water or excess of light stresses occur under this growing condition. We demonstrate that araucaria has low capacity to produce morphophysiological adjustments in response to the conditions provided by the forest canopy and these may explain its limited regeneration in the understory. Among the possible strategies to acclimate to shade observed in other species to enhance light use, only increase in specific leaf area is observed. The results suggest that the success of araucaria in restoration plans under canopy shade may not be guaranteed, because probably after 30 months, plants under the dense canopy would die by carbon starvation. However, as plant standardized hydraulic conductance is higher in shade plants than in sun plants hydraulics fails could compromise araucaria survival before carbon starvation, particularly if coverage is removed suddenly or under warmer climate. It would be advisable to carry out studies on the aptitude of the species to tolerate sudden variations in the canopy coverage and also over large gaps.

\section{ACKNOWLEDGMENT}

We thank the staff of Campo Anexo Manuel Belgrano (INTA EEA Montecarlo) in San Antonio, Misiones for helping in the experiment startups and for taking care of them. This Project was supported by Unidad para el Cambio Rural (UCAR), Ministerio de Agricultura, Ganadería y Pesca de la Nación, Argentina (PIA 12010 and 14031).

\section{REFERENCES}

Arnoni Costa E, AF Hess, CA Guimarães Finger. 2017. Estructura y Crecimiento de Los Bosques de Araucaria angustifolia En El Sur de Brasil. Bosque 38(2): 229-36. DOI: https:// doi.org/10.4067/S0717-92002017000200001

Beckert SM, MA Doetzer Rosot, CN Rosot. 2014. Crescimento e Dinâmica de Araucaria angustifolia (Bert.) O. Ktze. em Fragmento de Floresta Ombrófila Mista. Scientia Forestalis 42 (102): 209-18.

Cassana FF, CB Eller, RS Oliveira, LR Dillenburg. 2016. Effects of Soil Water Availability on Foliar Water Uptake of Araucaria angustifolia. Plant and Soil 399(1-2):147-157. DOI: https://doi.org/10.1007/s11104-015-2685-0

Dillenburg LR, LM Goncalves Rosa, M Mósena. 2010. Hypocotyl of Seedlings of the Large-Seeded Species Araucaria angustifolia: An Important Underground Sink of the Seed Reserves. Trees 24(4): 705-711. DOI: https://doi.org/10.1007/ s00468-010-0440-y

Di Rienzo JA, AW Guzman, F Casanoves. 2002. A MultipleComparisons Method Based on the Distribution of the Root Node Distance of a Binary Tree. Journal of Agricultural, Biological, and Environmental Statistics 7 (2): 129-42. DOI: https://doi.org/10.1198/10857110260141193

DiRienzo JA, F Casanoves, MG Balzarini, L Gonzalez, M Tablada, CW Robledo. 2017. InfoStat Versión 2012. Grupo InfoStat, FCA, Universidad Nacional de Córdoba, Argentina.

Duarte L da S, LR Dillenburg. 2000. Ecophysiological responses of Araucaria angustifolia (Araucariaceae) seedlings to different irradiance levels. Australian Journal of Botany 48(4): 531-37. DOI: https://doi.org/10.1071/BT98046

Duarte L da S, LR Dillenburg, LMG Rosa. 2002. Assessing the role of light availability in the regeneration of Araucaria angustifolia (Araucariaceae). Australian Journal of Botany 50: 741-51.

Einig W, A Mertz, R Hampp. 1999. Growth rate, Photosynthetic activity, and leaf development of Brazil Pine seedlings (Araucaria angustifolia [Bert.] O. Ktze. Plant Ecology 143: 23-28.

Franco MAS, LR Dillenburg. 2007. Ajustes morfológicos e fisiológicos em plantas jovens de Araucaria angustifolia ( Bertol .) Kuntze em resposta ao sombreamento. Hoehnea 34 (2): 135-44.

Gianoli E, F Valladares. 2012. Studying phenotypic plasticity : The advantages of a broad approach. Biological Journal of the Linnean Society 105(1): 1-7. DOI: https://doi. org/10.1111/j.1095-8312.2011.01793.x

Hacke UG, R Spicer, SG Schreiber, L Plavcová. 2017. An ecophysiological and developmental perspective on variation in vessel diameter. Plant Cell and Environment 40 (6): 831 45. DOI: https://doi.org/10.1111/pce.12777

Landhäusser SM, VJ Lieffers. 2001. Photosynthesis and carbon allocation of six boreal tree species grown in understory and open conditions. Tree Physiology 21 (4): 243-50. DOI: https://doi.org/10.1093/treephys/21.4.243

Longhi RV, PR Schneider, SJ Longhi, GP Marangon, E Arnoni Costa. 2018. Growth Dynamics of Araucaria after Management Interventions in Natural Forest. Floresta e Ambiente 25 (2): 1-10. DOI: http://dx.doi.org/10.1590/2179$\underline{8087.026415}$

Melcher PJ, NM Holbrook, MJ Burns, MA Zwieniecki, AR 
Cobb, TJ Brodribb, B Choat, L Sack. 2012. Measurements of Stem Xylem Hydraulic Conductivity in the Laboratory and Field. Methods in Ecology and Evolution 3 (4): 685-94. DOI: https://doi.org/10.1111/j.2041-210X.2012.00204.X

Moraes N, S Pires, JLM Gongalve, M Takaki, S Censi, JC Gongalves. 2000. Crescimento de Mudas de Algumas Espécies Arbóreas Que Ocorrem Na Mata Atlántica, Em Funcao Do Nível de Luminosidade. Revista Árvore 24 (1): 35-45.

Niinemets Ü. 2010. A Review of Light Interception in Plant Stands from Leaf to Canopy in Different Plant Functional Types and in Species with Varying Shade Tolerance. Ecological Research 25(4): DOI: 693-714. https://doi. org/10.1007/s11284-010-0712-4.

Paludo GF, A Mantovani, MS dos Reis. 2011. Regeneração de Uma População Natural de Araucaria angustifolia (Araucariaceae). Revista Árvore 35 (5): 1107-19.

Schoonmaker AL, UG Hacke, SM LandhäUsser, VJ Lieffers, MT Tyree. 2010. Hydraulic Acclimation to Shading in Boreal Conifers of Varying Shade Tolerance. Plant, Cell and Environment 33 (3): 382-93. DOI: https://doi.org/10.1111/ j.1365-3040.2009.02088.x

Souza AF, C Forgiarini, SJ Longhi, JM Oliveira. 2014. Detecting Ecological Groups from Traits : A Classification of Subtropical Tree Species Based on Ecological Strategies. Brazilian Journal of Botany 37 (4): 441-52. DOI: https:// doi.org/10.1007/s40415-014-0084-z

Strauss-Debenedetti S, FA Bazzaz. 1991. Plasticity and Acclimation to Light in Tropical Moraceae of Different Sucessional Positions. Oecologia 87: 377-87.

Valladares F, Ü Niinemets. 2008. Shade Tolerance, a Key Plant Feature of Complex Nature and Consequences. Annual Review of Ecology, Evolution, and Systematics 39 (1): 237-57. DOI: https://doi.org/doi:10.1146/annurev.ecolsys.39.110707.173506

Vieira TO, MSO Degli-Esposti, GM Souza, GR Rabelo, MDA Cunha, AP Vitoria. 2015. Photoacclimation Capacity in Seedling and Sapling of Siparuna guianensis (Siparunaeae): Response to Irradiance Gradient in Tropical Forest. Photosynthetica 53(1): 11-12. DOI: https://doi.org/10.1007/ s11099-015-0073-x

Wellburn AR. 1994. The Spectral Determination of Chlorophylls a and b, as Well as Total Carotenoids, Using Various Solvents with Spectrophotometers of Different Resolution. Journal of Plant Physiology 144 (3): 307-13. DOI: https:// doi.org/10.1016/S0176-1617(11)81192-2

Zhang Q, YJ Chen, LY Song, N Liu, LL Sun, CL. Peng. 2012. Utilization of Lightflecks by Seedlings of Five Dominant Tree Species of Different Subtropical Forest Successional Stages under Low-Light Growth Conditions. Tree Physiology 32 (5): 545-53. DOI: https://doi.org/10.1093/treephys/tps043

Recibido: 11/04/19

Aceptado: 27/08/19 
